\title{
IS MAINTAINED CRANIAL HYPOTHERMIA THE ONLY FACTOR LEADING TO IMPROVED OUTCOME AFTER RETROGRADE CEREBRAL PERFUSION? AN EXPERIMENTAL STUDY WITH A CHRONIC PORCINE MODEL
}

Vesa Anttila, MD

Matti Pokela, $\mathrm{MS}^{\mathrm{a}}$

Kai Kiviluoma, $\mathrm{MD}, \mathrm{PhD}^{\mathrm{b}}$

Minna Mäkiranta, $\mathrm{MSc}^{\mathrm{c}}$

Jorma Hirvonen, $\mathrm{MD}, \mathrm{PhD}^{\mathrm{d}}$

Tatu Juvonen, MD, $\mathrm{PhD}^{\mathrm{a}}$
Background: Previous studies have shown that retrograde cerebral perfusion can improve neurologic outcome after prolonged hypothermic circulatory arrest. Here we have compared two temperatures of retrograde cerebral perfusion $\left(15^{\circ} \mathrm{C}\right.$ and $\left.25^{\circ} \mathrm{C}\right)$ with hypothermic circulatory arrest at systemic hypothermia of $25^{\circ} \mathrm{C}$ to clarify whether the possible benefit of retrograde cerebral perfusion may only be due to improved cooling effect.

Methods: Eighteen pigs (23-27 kg) were randomly assigned to undergo $15^{\circ} \mathrm{C}$ retrograde cerebral perfusion at systemic hypothermia of $25^{\circ} \mathrm{C}$, $25^{\circ} \mathrm{C}$ retrograde cerebral perfusion at $25^{\circ} \mathrm{C}$ systemic hypothermia, or hypothermic circulatory arrest at $25^{\circ} \mathrm{C}$ for 40 minutes. Flow was adjusted to maintain superior vena cava pressure at $20 \mathrm{~mm} \mathrm{Hg}$ during retrograde cerebral perfusion. Hemodynamic, electrophysiologic, metabolic, and temperature monitoring were performed until 4 hours after the start of rewarming. Daily behavioral assessment was done until death or until the animals were killed on day 7 . Histopathologic analysis of the brain was carried out on all animals.

Results: Epidural temperatures were lower in the $15^{\circ} \mathrm{C}$ retrograde cerebral perfusion group during the intervention $(P<.05)$. In the $15^{\circ} \mathrm{C}$ retrograde cerebral perfusion group, $4(67 \%)$ of 6 animals survived for 7 days compared with $3(50 \%)$ of 6 in both the $25^{\circ} \mathrm{C}$ retrograde cerebral perfusion and hypothermic circulatory arrest groups. The median total histopathologic score was 5 in the $15^{\circ} \mathrm{C}$ retrograde cerebral perfusion group and 7 in the $25^{\circ} \mathrm{C}$ retrograde cerebral perfusion group $(P=.04)$.

Conclusions: These findings suggest that enhanced cranial hypothermia is the major beneficial factor of retrograde cerebral perfusion when careful attention is paid to its implementation. ( $\mathrm{J}$ Thorac Cardiovasc Surg 2000;119:1021-9)
From the Departments of Surgery and Anaesthesiology ${ }^{\mathrm{b}}$ and the Laboratory of Clinical Neurophysiology, ${ }^{c}$ Oulu University Hospital, and the Department of Forensic Medicine, ${ }^{\mathrm{d}}$ University of Oulu, Oulu, Finland.

This study was presented in abstract form at the Forty-eighth Annual Meeting of the Scandinavian Association for Thoracic Surgery (SATS) and awarded the Karl Victor Hall Award.

Supported by grants from Oulu University Hospital and the Finnish Heart Foundation. Dr Juvonen was supported by the Ingegerd and Viking Olov Björk Scholarship for Cardiothoracic Research.

Received for publication May 19, 1999; revisions requested Aug 23, 1999; revisions received Dec 1, 1999; accepted for publication Dec 16, 1999.

Address for reprints: Tatu Juvonen, MD, PhD, Department of Surgery, Oulu University Hospital, FIN 90220 Oulu, Finland (Email: tatu.juvonen@oulu.fi).

Copyright $\odot 2000$ by The American Association for Thoracic Surgery $0022-5223 / 2000 \$ 12.00+0 \quad \mathbf{1 2 / 1 / 1 0 5 2 0 8}$

doi: $10.1067 / \mathrm{mtc} .2000 .105208$
Qetrograde cerebral perfusion (RCP) was first used Zas a method to flush out massive air embolism during cardiopulmonary bypass (CPB). ${ }^{1}$ One decade ago, this method was introduced as a means to improve cerebral protection during hypothermic circulatory arrest (HCA). ${ }^{2}$ Since then, RCP has been adopted with great enthusiasm, especially for operations of the aortic arch. The most ardent proponents of RCP are convinced that this method is effective in reducing embolic injury and in prolonging the permissible period of HCA. ${ }^{3}$ Many clinical reports support these hypotheses, providing evidence of improved neurologic outcome after the use of $\mathrm{RCP}^{4-6}$ However, at the same time, there exists much evidence that RCP per se seems to carry an increased risk of perfusion-induced cerebral injury, especially if high perfusion pressures are used..$^{7-9}$ Therefore it is clear that the details of RCP implementation are very 
critical to provide benefit without inducing damage from the cerebral edema. According to current information, the use of RCP for cerebral protection during HCA is safe when flow rates and central venous pressures are maintained at relatively low levels. ${ }^{10}$ This raises the question that the apparent superiority of RCP compared with HCA may be due to an improved cooling effect. This mechanism is supported by the fact that RCP provides only a small percentage of the nutrient flow necessary to sustain cerebral metabolism, even in the presence of deep hypothermia. ${ }^{11}$

We have been studying RCP in a chronic porcine model in which the metabolic and physiologic consequences of different interventions can be evaluated during operation and the possible cerebral injury can be assessed by means of electrophysiologic recovery, behavioral evaluation, and histopathologic examination after the animals are killed 1 week postoperatively. Our studies have thus far indicated that cold RCP may enhance cerebral protection during prolonged HCA when compared with HCA alone, even when the head is packed in ice. ${ }^{12}$ In the current study we have compared two temperatures of $\mathrm{RCP}\left(15^{\circ} \mathrm{C}\right.$ and $\left.25^{\circ} \mathrm{C}\right)$ with $\mathrm{HCA}$ at systemic hypothermia of $25^{\circ} \mathrm{C}$ to clarify whether the possible benefit of RCP may be due to an improved cooling effect.

\section{Materials and methods}

Eighteen female juvenile (8-10 weeks) pigs of a native stock, weighing 23 to $27 \mathrm{~kg}$, were randomly assigned to undergo 40 minutes of one of the following procedures at $25^{\circ} \mathrm{C}$ systemic hypothermia: $\operatorname{RCP}\left(15^{\circ} \mathrm{C}\right), \operatorname{RCP}\left(25^{\circ} \mathrm{C}\right)$, and HCA alone.

Preoperative management. All animals received humane care in accordance with the "Principles of Laboratory Animal Care" formulated by the National Society for Medical Research and the "Guide for the Care and Use of Laboratory Animals" prepared by the Institute of Laboratory Animal Resources and published by the National Institutes of Health (National Institutes of Health publication No. 85-23, revised 1985). The study was approved by the Research Animal Care and Use Committee of the University of Oulu.

Anesthesia and hemodynamic monitoring. Anesthesia was induced with ketamine hydrochloride $(10 \mathrm{mg} / \mathrm{kg}$ administered intramuscularly) and midazolam $(1 \mathrm{mg} / \mathrm{kg}$ administered intramuscularly), and muscular paralysis was maintained with pancuronium $(0.1 \mathrm{mg} / \mathrm{kg}$ administered intravenously). After endotracheal intubation, the animals were maintained on positive-pressure ventilation with $100 \%$ oxygen; anesthesia was maintained with isoflurane $(1.1 \%$ $1.2 \%)$. The arterial catheter was positioned in the left femoral artery. A thermodilution catheter (CritiCath, 7F; Ohmeda $\mathrm{GmbH} \& \mathrm{Co}$, Erlangen, Germany) was placed through the femoral vein to allow blood sampling, pressure monitoring in the pulmonary artery, and recording of cardiac output. The intracranial temperature probe was placed trough a drill hole in the epidural space positioned $1 \mathrm{~cm}$ to the right side from a sagittal joint above a parietal line. Other temperature probes were placed in the esophagus and rectum, and a 10-Ch nelaton catheter (Braun Melsungen AG, Melsungen, Germany) was placed in the urinary bladder.

Electroencephalography monitoring. Cortical electrical activity was registered from 4 stainless steel screw electrodes (5 $\mathrm{mm}$ in diameter) implanted in the skull over the parietal and frontal areas of the cortex by using a digital electroencephalography (EEG) recorder (Nervus, Reykjovik, Iceland) and an amplifier (Magnus EEG 32/8, Reykjovik, Iceland). Sampling frequency was $1024 \mathrm{~Hz}$, with a bandwidth of 0.03 to $256 \mathrm{~Hz}$. All EEG recordings were referenced to a frontal screw electrode, which, together with a ground screw electrode, was implanted over the frontal sinuses. Continuous EEG activity was recorded for 10 minutes in anesthesia before the cooling period (baseline) and after intervention until 4.5 hours. During anesthesia, the EEG showed a burstsuppression pattern. Thus the recovery of the EEG was measured by the EEG burst ratio, which was calculated as the summation of burst lengths divided by the length of the recording.

Cardiopulmonary bypass. A right thoracotomy in the fourth intercostal space was performed, the right thoracic artery and azygous vein were ligated, and the hemiazygos vein was snared. The superior vena cava (SVC) was mobilized. A membrane oxygenator (Midiflow D 705; Dideco, Mirandola, Italy) was primed with $1 \mathrm{~L}$ of Ringer acetate and heparin $(5000 \mathrm{IU})$. After heparinization $(300 \mathrm{IU} / \mathrm{kg})$, the ascending aorta was cannulated with a $16 \mathrm{~F}$ arterial cannula, and the right atrial appendage was cannulated with a single $24 \mathrm{~F}$ atrial cannula. Nonpulsatile CPB was initiated at a flow rate of $100 \mathrm{~mL} \cdot \mathrm{kg}^{-1} \cdot \mathrm{min}^{-1}$, and the flow was adjusted to maintain $50 \mathrm{~mm} \mathrm{Hg}$ of perfusion pressure. A $12 \mathrm{~F}$ intracardial sump cannula was positioned into the left ventricle for decompression of the left side of the heart during CPB. A heat exchanger was used for core cooling. The $\mathrm{pH}$ was maintained, by using alpha-stat principles, at $7.40 \pm 0.05$, with an arterial carbon dioxide tension of 3.5 to $4.0 \mathrm{kPa}$ uncorrected for temperature. All measurements were performed at $37^{\circ} \mathrm{C}$.

The cooling period of 50 minutes was carried out to attain both rectal and epidural temperatures at $25^{\circ} \mathrm{C}$. The ascending aorta was crossclamped just proximal to the aortic cannula. Cardiac arrest was induced by injecting potassium chloride (1 $\mathrm{mEq} / \mathrm{kg}$ ) to the aortic cannula, and topical cardiac cooling was used throughout the aortic crossclamp period.

Experimental protocol. After aortic crossclamping, the blood volume was drained from the venous line into the reservoir. The animals underwent a 40-minute interval of HCA or 5 minutes of HCA following 35 minutes of $\operatorname{RCP}\left(15^{\circ} \mathrm{C}\right)$ or $\operatorname{RCP}\left(25^{\circ} \mathrm{C}\right)$, as dictated by the randomization protocol. Head packing in ice was not used in any of the groups.

Preparations for RCP involved inserting an $18 \mathrm{~F}$ cannula into the SVC, advancing it as cranially as possible, snaring it in place, and connecting it to the arterial line with a Y connector. The inferior vena cava (IVC) was not occluded. Retrograde 
flow was slowly increased and regulated to attain an SVC pressure of $20 \mathrm{~mm} \mathrm{Hg}$. In the RCP groups perfusate returning from the upper body to the ascending aorta was drained to the collecting chamber and returned to the pump once its volume had been measured. The amount of sequestered blood volume was calculated as the difference between the reservoir volume at the beginning and the end of RCP.

After 40 minutes, rewarming was initiated, the SVC and the left ventricular vent cannulas were removed, and the snared hemiazygos vein was released. Weaning from CPB occurred approximately 60 minutes after the start of rewarming with administration of furosemide (40 mg), mannitol (15.0 g), methylprednisolone (80 mg), and lidocaine (40-150 $\mathrm{mg}$ ). Cardiac support was provided by dopamine. Animals were kept in isoflurane anesthesia until the following morning, extubated, and moved into a recovery room.

During the experiments, hemodynamic and metabolic measurements were recorded at 5 different time points as follows: (1) at baseline, after the thermodilution catheter was positioned; (2) at the end of cooling, at $25^{\circ} \mathrm{C}$; (3) during rewarming, at $30^{\circ} \mathrm{C}$; (4) 2 hours after the start of rewarming; and (5) 4 hours after the start of rewarming.

Postoperative evaluation. Postoperatively, all the animals were evaluated daily by using a species-specific quantitative behavioral score, as reported earlier. ${ }^{9}$ The assessment quantified mental status $(0=$ comatose, $1=$ stuporous, $2=$ depressed, and $3=$ normal $)$, appetite $(0=$ refuses liquids, $1=$ refuses solids, $2=$ decreased, and $3=$ normal $)$, and motor function $(0$ $=$ unable to stand, $1=$ unable to walk, $2=$ unsteady gait, and $3=$ normal). Numerical summing of these functions provides a final score; a score of 9 reflects apparently normal neurologic function, whereas lower values indicate substantial neurologic damage. Each surviving animal was electively killed on day 7 after surgery. The entire brain was immediately harvested and weighed for subsequent histologic analysis.

Histopathologic analysis. During autopsy, the hemispheres were cut apart. One half was immersed in $10 \%$ neutral formalin and allowed to fix for 2 weeks en bloc. Thereafter, 3-mm thick coronal samples were sliced from the frontal lobe, thalamus (including the adjacent cortex), and hippocampus (including the adjacent brain stem and temporal cortex), and sagittal samples were taken from the posterior brain stem (medulla oblongata and pons) and cerebellum. The pieces were fixed in fresh formalin for another week. After the fixation, the samples were processed as follows: rinsing in water for 20 minutes and immersion in $70 \%$ ethanol for 2 hours, in $94 \%$ ethanol for 4 hours, and in absolute ethanol for 9 hours. Thereafter, the pieces were kept for 1 hour in an absolute ethanol-xylene mixture and 4 hours in xylene and embedded in warm paraffin for 6 hours. The samples were sectioned at $6 \mu \mathrm{m}$ and stained with hematoxylin and eosin stain. The sections of the brain samples of each animal were screened by a single experienced senior pathologist (J.H.) who was unaware of the experimental design and the identity and fate of individual animals. Each section was carefully investigated for the presence or absence of any hypoxic or other damage.
Visual estimation of the injuries in the sampled regions was made as follows: 0 indicates no morphologic damage identified; 1 indicates edema, occasional dark neurons, or both; 2 indicates numerous dark neurons (often also shrunk) and eosinophilic or dark-shrunk cerebellar Purkinje cells or hemorrhages; and 3 indicates clearly infarctive foci with neoformation of capillaries and the presence of macrophages and glial reactions.

To allow semiquantitative comparisons between the animals, a total histologic score was calculated by adding all the regional scores. A score of more than 4 means that the animal had a distinct brain injury.

Other measurements. Systemic arterial and venous blood samples were obtained to determine $\mathrm{pH}$, oxygen tension, carbon dioxide tension, oxygen saturation, oxygen content, and hematocrit, hemoglobin, and glucose levels (Ciba-Corning 288 Blood Gas System; Ciba-Corning Diagnostic Corp, Medfield, Mass). Lactate was analyzed by using a YSI 1500 analyzer (Yellow Springs Instrument Co, Yellow Springs, Ohio). Hemodynamics, temperatures, and respiratory gases were monitored by using the Datex $\mathrm{AS} / 3$ anesthesia monitor (Datex Inc, Espoo, Finland).

Statistical analysis. Summary statistics for continuous or ordinal variables are expressed as the median with interquartile range (IQR; 25th and 75th percentile). The analyses were performed by using 2-way analysis of variance. Comparison between relevant time points and baseline (reference category) was performed by using the paired samples $t$ test or the Wilcoxon matched pairs signed rank test. Differences between groups were determined by $t$ tests or the MannWhitney $U$ test. The multiple comparison problem was controlled by means of the Bonferroni method. To determine correlation between histopathologic score and epidural temperature at the end of the HCA, Kendall's $(\tau)$ correlation coefficient was used. The levels of statistical significance should be interpreted with caution, given the large number of statistical tests performed. Analyses were performed by using a standard, commercially available, statistical program (SPSS 9.0; SPSS Inc, Chicago, Ill).

\section{Results}

\section{Physiologic data}

Comparability of experimental groups. The median weight of the animals was $25 \mathrm{~kg}$ (IQR, 24-27 kg) in the HCA group, $25 \mathrm{~kg}$ (IQR, 25-26 kg) in the RCP $\left(15^{\circ} \mathrm{C}\right)$ group, and $24 \mathrm{~kg}$ (IQR, 23-25 kg) in the $\operatorname{RCP}\left(25^{\circ} \mathrm{C}\right)$ group $(P>.2)$. The median cooling time was $49 \mathrm{~min}-$ utes (IQR, 45-54 minutes) in the HCA group, 53 minutes (IQR, $45-63$ minutes) in the $\mathrm{RCP}\left(15^{\circ} \mathrm{C}\right)$ group, and 54 minutes (IQR, 50-58 minutes) in the $\mathrm{RCP}\left(25^{\circ} \mathrm{C}\right)$ group $(P>.2)$. The median rewarming times were, respectively, 64 minutes (IQR, 60-68 minutes), 63 minutes (IQR, 50-72 minutes), and 64 minutes (IQR, 47-71 minutes) $(P>.2)$.

Epidural temperatures were lower in the $\operatorname{RCP}\left(15^{\circ} \mathrm{C}\right)$ group in every recording point beginning 10 minutes 


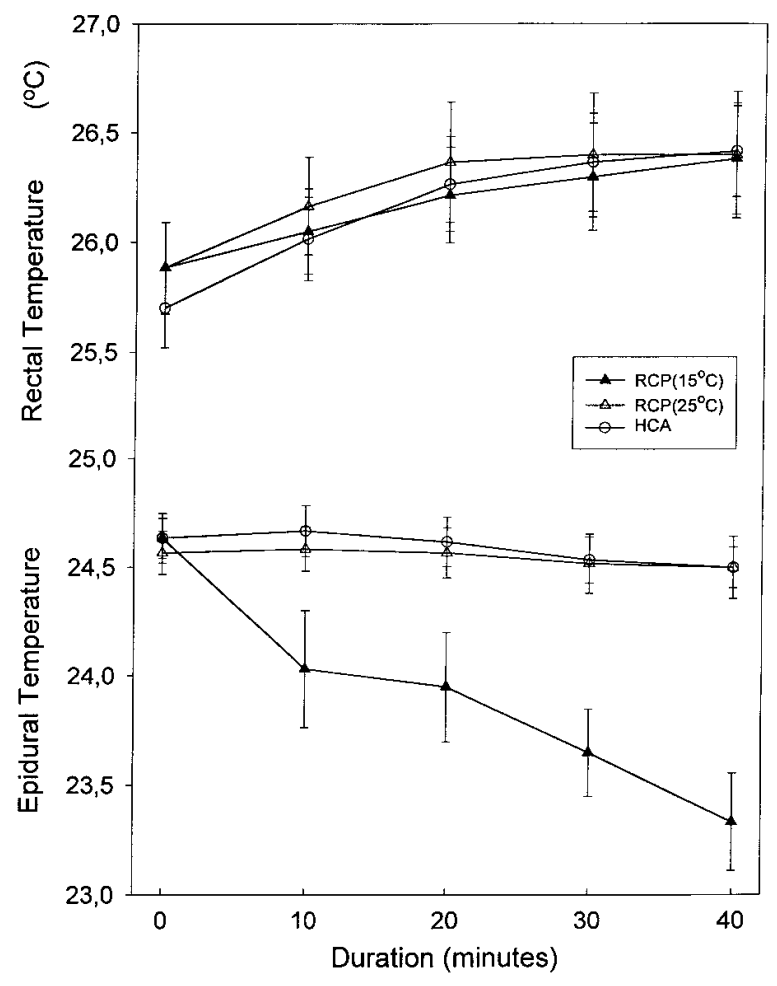

Fig 1. Epidural temperatures of 18 pigs undergoing 40minute periods of either $\mathrm{HCA}$ at a systemic temperature of $25^{\circ} \mathrm{C}$ or $\mathrm{RCP}$ with $25^{\circ} \mathrm{C}$ or $15^{\circ} \mathrm{C}$ perfusate. Values are shown as medians with IQRs.

after the onset of the intervention $(P<.05)$. This difference was found to be increased through the intervention. Rectal temperature showed some drift upward from baseline in every group (Fig 1).

Hemodynamic data. All animals were stable before, during, and after CPB. There were no significant differences in hemodynamic measurements between the groups (Table I).

Blood gas and hematocrit measurement. The $\mathrm{RCP}\left(15^{\circ} \mathrm{C}\right)$ group had a decrease in $\mathrm{pH}$ at 2 hours after the start of rewarming when compared with baseline $(P$ $=.03$ ), but differences between the groups were not seen. The hematocrit level decreased during the RCP period in both RCP groups (Table II).

Metabolic data. The venous lactate levels increased after intervention in every group, but there were no significant differences between the groups (Table III). The oxygen extraction and consumption did not differ between the groups (Table IV).

Retrograde flow. There were no differences in SVC inflow, aortic arch return, and volume of blood sequestration during the intervention between the two RCP groups (Table V).
Morbidity and mortality. All animals were stable during the procedures and survived to the first postoperative day. Ten $(55 \%)$ of the 18 animals survived until 7 days after surgery and were electively killed. In the $\mathrm{RCP}\left(15^{\circ} \mathrm{C}\right)$ group, $4(67 \%)$ of 6 animals survived for 7 days compared with 3 (50\%) of 6 in both of the other two groups $(P>.2)$.

Behavioral outcome. The results of behavioral scoring for all 3 groups are shown in Fig 2. Animals that died early were given a score of zero beginning at the time of death. Complete behavioral recovery was seen in 3 of 6 after $\operatorname{RCP}\left(15^{\circ} \mathrm{C}\right)$ compared with none in the other 2 groups. Among the animals that survived for 7 days, the median behavioral score was lower in animals after $\operatorname{RCP}\left(15^{\circ} \mathrm{C}\right)$ compared with $\operatorname{RCP}\left(25^{\circ} \mathrm{C}\right)$ or HCA $(P=.02$ and $P=.03$, respectively).

Histopathologic observations. The microscopic investigations were carried out in 18 brains, and the raw data are given in Table VI. The most striking findings were tiny hemorrhages or extravasations (both scored as 2), which were mostly located in the deeper axonal layer (white matter). There were no glial or macrophage reactions around the hemorrhages. The bleeding could thus be fresh or 1 week old. Small infarctions (scored as 3 ) were seen in the frontal cortex in 3 pigs after $\operatorname{RCP}\left(25^{\circ} \mathrm{C}\right)$ and one in the thalamus of the animal after HCA. The lesion contained macrophages, macroglial reactions, and new capillaries, indicating old damage. Hemorrhage was not present in these lesions. Dark neurons, which in some cases were also shrunk, were considered as a slight sign of injury (scored as 1) when no necrotic foci or hemorrhages were observed. Histopathologic scoring of the cerebellum was lower in the $\operatorname{RCP}\left(15^{\circ} \mathrm{C}\right)$ group than in the $\operatorname{RCP}\left(25^{\circ} \mathrm{C}\right)$ group $(P=$ .01 ; Table VI).

The total histopathologic score varied between 1 and 10. As seen in Fig 3, the scores in the $\operatorname{RCP}\left(15^{\circ} \mathrm{C}\right)$ group were significantly lower than those found in the $\operatorname{RCP}\left(25^{\circ} \mathrm{C}\right)$ group $(P=.04)$. The scores in the $\operatorname{RCP}\left(15^{\circ} \mathrm{C}\right)$ group tended to be lower than those found in the HCA group $(P=.1)$. The epidural temperature at the end of intervention was found to be positively correlated with the total histopathologic score $(\tau=0.27, P$ $=.07$; Fig 4).

EEG. EEG bursts were recovered significantly better in the $\mathrm{RCP}\left(15^{\circ} \mathrm{C}\right)$ group at 3 hours after the start of rewarming than in the HCA group $(P=.05)$, but a regression was seen half an hour later. After this, bursts recovered similarly in both RCP groups, although they were slightly slower in the HCA group (Fig 5). 
Table I. Hemodynamic data in 18 pigs undergoing 40 -minute periods of $H C A, R C P\left(15^{\circ} \mathrm{C}\right)$, or $R C P\left(25^{\circ} \mathrm{C}\right)$

\begin{tabular}{lcccccc}
\hline & & Baseline & End of CPB cooling & & \multicolumn{2}{c}{ After start of rewarming } \\
\cline { 5 - 7 } Group & $n$ & $\left(37^{\circ} \mathrm{C}\right)$ & $\left(25^{\circ} \mathrm{C}\right)$ & $30^{\circ} \mathrm{C}$ & $2 h$ & $4 h$ \\
\hline MAP $(\mathrm{mm} \mathrm{Hg})$ & & & & & & \\
HCA & 6 & $78(68-87)$ & $54(50-55)$ & $56(50-55)$ & $61(55-65)$ & $68(67-70)$ \\
RCP $\left(15^{\circ} \mathrm{C}\right)$ & 6 & $82(73-92)$ & $55(53-57)$ & $55(53-62)$ & $63(54-67)$ & $72(67-77)$ \\
RCP $\left(25^{\circ} \mathrm{C}\right)$ & 6 & $71(68-86)$ & $53(52-55)$ & $53(52-55)$ & $62(60-66)$ & $71(63-75)$ \\
Cardiac output/CPB flow (L/min) & 6 & $3.5(3.1-3.6)$ & $2.5(2.2-3.0)$ & $2.5(2.4-2.7)$ & $3.5(3.1-3.5)$ & $3.1(2.7-3.5)$ \\
HCA & 6 & $3.5(3.4-3.7)$ & $2.5(2.0-2.6)$ & $2.3(2.0-2.4)$ & $3.5(3.1-3.8)$ & $3.2(2.7-3.4)$ \\
RCP $\left(15^{\circ} \mathrm{C}\right)$ & 6 & $3.2(2.7-3.6)$ & $2.2(2.0-2.3)$ & $2.1(1.8-2.4)$ & $3.4(3.0-3.7)$ & $2.5(2.4-2.9)$ \\
RCP $\left(25^{\circ} \mathrm{C}\right)$ & & &
\end{tabular}

Values are shown as medians with IQRs. MAP, Mean arterial pressure.

Table II. Blood gases and hematocrit levels in 18 pigs undergoing 40 -minute periods of $H C A, R C P\left(15^{\circ} \mathrm{C}\right)$, or $R C P\left(25^{\circ} \mathrm{C}\right)$

\begin{tabular}{|c|c|c|c|c|c|c|c|}
\hline \multirow[b]{2}{*}{ Group } & \multirow[b]{2}{*}{$n$} & \multirow{2}{*}{$\begin{array}{c}\text { Baseline } \\
\left(37^{\circ} \mathrm{C}\right)\end{array}$} & \multirow{2}{*}{$\begin{array}{l}\text { End of } C P B \text { cooling } \\
\qquad\left(25^{\circ} \mathrm{C}\right)\end{array}$} & \multirow[b]{2}{*}{ Stable RCP } & \multirow[b]{2}{*}{$30^{\circ} \mathrm{C}$} & \multicolumn{2}{|c|}{ After start of rewarming } \\
\hline & & & & & & $2 h$ & $4 h$ \\
\hline \multicolumn{8}{|l|}{ Arterial $\mathrm{pH}$} \\
\hline HCA & 6 & 7.47 (7.45-7.48) & $7.48(7.40-7.53)$ & - & $7.44(7.42-7.46)$ & 7.37 (7.34-7.40) & $7.44(7.42-7.45)$ \\
\hline $\operatorname{RCP}\left(15^{\circ} \mathrm{C}\right)$ & 6 & 7.47 (7.45-7.49) & $7.46(7.40-7.52)$ & $7.71(7.59-7.77)$ & $7.44(7.43-7.52)$ & $7.33(7.30-7.39)^{*}$ & $7.43(7.39-7.46)$ \\
\hline $\mathrm{RCP}\left(25^{\circ} \mathrm{C}\right)$ & 6 & $7.46(7.45-7.47)$ & 7.47 (7.44-7.49) & $7.78(7.62-7.81)$ & 7.43 (7.39-7.47) & 7.37 (7.32-7.38) & $7.42(7.42-7.43)$ \\
\hline \multicolumn{8}{|l|}{$\mathrm{PaCO}_{2}(\mathrm{kPa})$} \\
\hline $\mathrm{HCA}$ & 6 & $5.97(5.86-6.16)$ & $4.92(4.47-5.54)$ & - & $3.98(3.69-4.05) \dagger$ & $6.17(5.95-6.53)$ & $6.21(5.94-6.58)$ \\
\hline $\mathrm{RCP}\left(15^{\circ} \mathrm{C}\right)$ & 6 & $5.84(5.47-6.09)$ & $5.39(4.66-5.70)$ & $2.59(2.36-3.55) \dagger$ & $3.76(3.18-4.26) \ddagger$ & $6.51(6.39-6.58)$ & $6.37(6.20-6.86)$ \\
\hline $\mathrm{RCP}\left(25^{\circ} \mathrm{C}\right)$ & 6 & $5.91(5.78-5.95)$ & $4.89(4.82-5.03)$ & $1.88(1.36-3.04) \dagger$ & $3.61(3.32-3.87) \dagger$ & $6.05(5.97-6.43)$ & $6.33(6.31-6.43)$ \\
\hline \multicolumn{8}{|c|}{ Hematocrit level } \\
\hline $\mathrm{HCA}$ & 6 & $27.0(25.3-29.7)$ & $18.4(17.1-20.0)^{*}$ & - & $19.3(16.5-22.1)^{*}$ & $24.1(22.5-29.0)$ & $24.2(23.5-25.3)$ \\
\hline $\mathrm{RCP}\left(15^{\circ} \mathrm{C}\right)$ & 6 & $27.5(24.4-28.8)$ & $19.4(18.8-20.6)^{*}$ & $18.0(16.6-20.0)^{*}$ & $19.3(17.9-20.3)$ & $24.0(21.2-25.3)$ & $25.2(24.1-26.2)$ \\
\hline $\mathrm{RCP}\left(25^{\circ} \mathrm{C}\right)$ & 6 & $28.2(28.2-33.2)$ & $19.1(18.8-24.1) \dagger$ & 17.4 (16.0-19.3)* & $18.2(16.8-20.0)^{*}$ & $24.7(22.4-27.1)$ & $25.9(24.7-28.5)$ \\
\hline
\end{tabular}

Values are shown as medians with IQRs.

$* P<.05$ compared with baseline.

$\dagger P<.001$ compared with baseline.

$\ddagger P<.0001$ compared with baseline

\section{Discussion}

The major findings of the present studies were distinctly better neurophysiologic, neurologic, and histopathologic outcome in animals undergoing $\operatorname{RCP}\left(15^{\circ} \mathrm{C}\right)$ compared with $\operatorname{RCP}\left(25^{\circ} \mathrm{C}\right)$, and there tended to be a difference compared with $25^{\circ} \mathrm{C}$ HCA. The animals in the $\operatorname{RCP}\left(15^{\circ} \mathrm{C}\right)$ group had lower epidural temperatures during the intervention than those in both the $\operatorname{RCP}\left(25^{\circ} \mathrm{C}\right)$ and $25^{\circ} \mathrm{C}$ HCA groups, which may have contributed to their improved outcome. We believe that the better temperature control is the only factor leading to improved outcome because animals undergoing $\mathrm{RCP}\left(25^{\circ} \mathrm{C}\right)$ did not have a better outcome compared with HCA animals. Head packing in ice was not used in this study. These findings suggest that nutrient RCP flow was not generated in ani- mals undergoing $\operatorname{RCP}\left(25^{\circ} \mathrm{C}\right)$ in the present experiments.

Total histopathologic and cerebellum scores in the $\operatorname{RCP}\left(15^{\circ} \mathrm{C}\right)$ group were lower than those found in the $\operatorname{RCP}\left(25^{\circ} \mathrm{C}\right)$ group. Brain infarctions were seen in 3 animals after $\operatorname{RCP}\left(25^{\circ} \mathrm{C}\right)$ and in 1 after $\mathrm{HCA}$, although they were found in none after $\operatorname{RCP}\left(15^{\circ} \mathrm{C}\right)$. It can be speculated that the most severe infarctions had no time to develop in animals who died at the first day after the operation. The rates of early deaths did not differ between the groups, and therefore it is hard to believe that the central observation of this study might have been interpreted differently if histopathologic values were recorded on day 7 in each animal.

It is very difficult to study RCP experimentally because there exist several differences in anatomy and 
Table III. Metabolic data in 18 pigs undergoing 40 -minute periods of $H C A, R C P\left(15^{\circ} \mathrm{C}\right)$, or $R C P\left(25^{\circ} \mathrm{C}\right)$

\begin{tabular}{|c|c|c|c|c|c|c|}
\hline \multirow[b]{2}{*}{ Group } & \multirow[b]{2}{*}{$n$} & \multirow{2}{*}{$\begin{array}{c}\text { Baseline } \\
\left(37^{\circ} \mathrm{C}\right)\end{array}$} & \multirow{2}{*}{$\begin{array}{c}\text { End of } C P B \text { cooling } \\
\left(25^{\circ} \mathrm{C}\right)\end{array}$} & \multirow[b]{2}{*}{$30^{\circ} \mathrm{C}$} & \multicolumn{2}{|c|}{ After start of rewarming } \\
\hline & & & & & $2 h$ & $4 h$ \\
\hline \multicolumn{7}{|c|}{ Venous lactate (mmol/L) } \\
\hline HCA & 6 & $0.67(0.60-0.68)$ & $1.44(1.30-1.69)$ & $6.21(5.35-6.46) \ddagger$ & $3.33(2.87-3.38)^{*}$ & $1.26(1.21-1.40)$ \\
\hline $\mathrm{RCP}\left(15^{\circ} \mathrm{C}\right)$ & 6 & $0.87(0.69-1.09)$ & $1.58(1.55-1.72)$ & $6.06(5.90-6.10) \ddagger$ & $3.39(3.27-4.10) \dagger$ & $1.23(1.23-1.55)$ \\
\hline $\operatorname{RCP}\left(25^{\circ} \mathrm{C}\right)$ & 6 & $1.01(0.95-1.21)$ & $2.14(1.49-2.23)$ & $6.33(6.16-6.86) \dagger$ & $4.03(3.38-4.87)^{*}$ & $1.30(1.19-1.49)$ \\
\hline \multicolumn{7}{|c|}{ Venous glucose (mmol/L) } \\
\hline $\mathrm{HCA}$ & 6 & $4.6(4.4-4.8)$ & $3.9(3.5-4.3)^{*}$ & $8.8(8.8-10.2)$ & $5.7(5.6-6.5)^{*}$ & $5.3(5.1-6.0)$ \\
\hline $\mathrm{RCP}\left(15^{\circ} \mathrm{C}\right)$ & 6 & $5.1(5.0-5.1)$ & $5.0(4.5-6.0)$ & $9.4(9.3-10.5)$ & $6.3(5.2-6.4)$ & $5.5(5.1-5.8)$ \\
\hline $\operatorname{RCP}\left(25^{\circ} \mathrm{C}\right)$ & 6 & $4.8(4.7-4.8)$ & $4.5(4.3-5.0)$ & $12.6(9.0-12.7)$ & $8.0(5.0-8.8)$ & $6.4(4.8-6.6)$ \\
\hline
\end{tabular}

Values are shown as medians with IQRs.

$* P<.05$ compared with baseline.

$\dagger P<.001$ compared with baseline.

$\ddagger P<.0001$ compared with baseline.

Table IV. Oxygen extraction and consumption during the experiment in 18 pigs undergoing 40-minute periods of $H C A, R C P\left(15^{\circ} \mathrm{C}\right)$, or $R C P\left(25^{\circ} \mathrm{C}\right)$

\begin{tabular}{|c|c|c|c|c|c|c|c|}
\hline \multirow[b]{2}{*}{ Group } & \multirow[b]{2}{*}{$n$} & \multirow{2}{*}{$\begin{array}{c}\text { Baseline } \\
\left(37^{\circ} \mathrm{C}\right)\end{array}$} & \multirow{2}{*}{$\begin{array}{c}\text { End of } C P B \text { cooling } \\
\left(25^{\circ}\right)\end{array}$} & \multirow[b]{2}{*}{ Stable $R C P$} & \multirow[b]{2}{*}{$30^{\circ} \mathrm{C}$} & \multicolumn{2}{|c|}{ After start of rewarming } \\
\hline & & & & & & $2 h$ & $4 h$ \\
\hline \multicolumn{8}{|c|}{$\begin{array}{l}\text { Oxygen extraction } \\
(\mathrm{mL} / \mathrm{dL})\end{array}$} \\
\hline $\mathrm{HCA}$ & 6 & $2.5(2.5-2.9)$ & $1.5(1.4-2.5)$ & - & $3.7(3.5-3.7)$ & $2.7(2.6-2.9)$ & $3.3(3.1-4.2)$ \\
\hline $\operatorname{RCP}\left(15^{\circ} \mathrm{C}\right)$ & 6 & $2.5(2.2-2.9)$ & $2.1(1.6-2.3)$ & $8.4(7.8-8.4) \ddagger$ & $3.8(3.6-4.6)$ & $2.9(2.8-3.1)$ & $3.6(3.1-3.7)$ \\
\hline $\operatorname{RCP}\left(25^{\circ} \mathrm{C}\right)$ & 6 & $3.0(2.9-3.0)$ & $2.6(2.6-3.2)$ & $7.7(7.6-9.1)^{*}$ & $4.1(3.2-4.6)$ & $2.8(2.7-2.9)$ & $3.4(3.2-3.5)$ \\
\hline \multicolumn{8}{|c|}{$\begin{array}{l}\text { Oxygen consumption } \\
(\mathrm{mL} / \mathrm{min})\end{array}$} \\
\hline $\mathrm{HCA}$ & 6 & $96.1(90.3-105.0)$ & $56.0(49.0-58.8)$ & - & $88.9(81.2-126.4)$ & $93.4(86.5-105.7)$ & $111.7(108.2-114.1)$ \\
\hline $\operatorname{RCP}\left(15^{\circ} \mathrm{C}\right)$ & 6 & $87.0(85.3-93.1)$ & $44.4(41.6-47.8)$ & $9.2(8.6-10.9)^{*}$ & $91.6(87.4-92.8)$ & $96.0(90.8-118.7)$ & $110.9(97.2-120.3)$ \\
\hline $\operatorname{RCP}\left(25^{\circ} \mathrm{C}\right)$ & 6 & $90.0(88.3-106.8)$ & $60.0(52.0-79.2)$ & $6.2(6.1-10.4)^{*}$ & $91.4(82.8-94.9)$ & $99.0(97.4-100.2)$ & $102.4(84.0-102.6)$ \\
\hline
\end{tabular}

Values are shown as medians with IQRs.

$* P<.05$ compared with baseline.

$\dagger P<.001$ compared with baseline.

$\ddagger P<.0001$ compared with baseline.

Table V. SVC inflow, blood return, and sequestration volume during RCP

\begin{tabular}{llllll}
\hline & & & \multicolumn{2}{c}{ Return blood flow (mL/min) } \\
\cline { 3 - 5 } Group & $n$ & $\begin{array}{c}\text { SVC inflow } \\
(\mathrm{mL} / \mathrm{min})\end{array}$ & $\begin{array}{c}\text { Ascending } \\
\text { aorta }\end{array}$ & $\begin{array}{c}\text { Right } \\
\text { atrium }\end{array}$ & $\begin{array}{c}\text { Blood sequestration } \\
(\mathrm{mL})\end{array}$ \\
\hline $\mathrm{RCP}\left(15^{\circ} \mathrm{C}\right)$ & 6 & $125(110-140)$ & $7(5-14)$ & $113(80-120)$ & $250(200-290)$ \\
$\mathrm{RCP}\left(25^{\circ} \mathrm{C}\right)$ & 6 & $100(80-120)$ & $5(4-8)$ & $85(76-102)$ & $245(100-300$ \\
\hline
\end{tabular}

Values are shown as medians with IQRs.

physiology of cerebral venous circulation among species used in laboratory investigations. ${ }^{13}$ The major question concerns the feasibility to generate effective RCP beyond competent jugular valves. ${ }^{14} \mathrm{~A}$ study performed on monkeys indicated that less than $1 \%$ of blood returned to the aortic arch during RCP, and more than $90 \%$ was shunting to the IVC. ${ }^{11}$ This was supported by a cadaver study indicating that there are competent jugular valves in $85 \%$ of human beings and that the valve-free azygos vein system is the major pathway to 


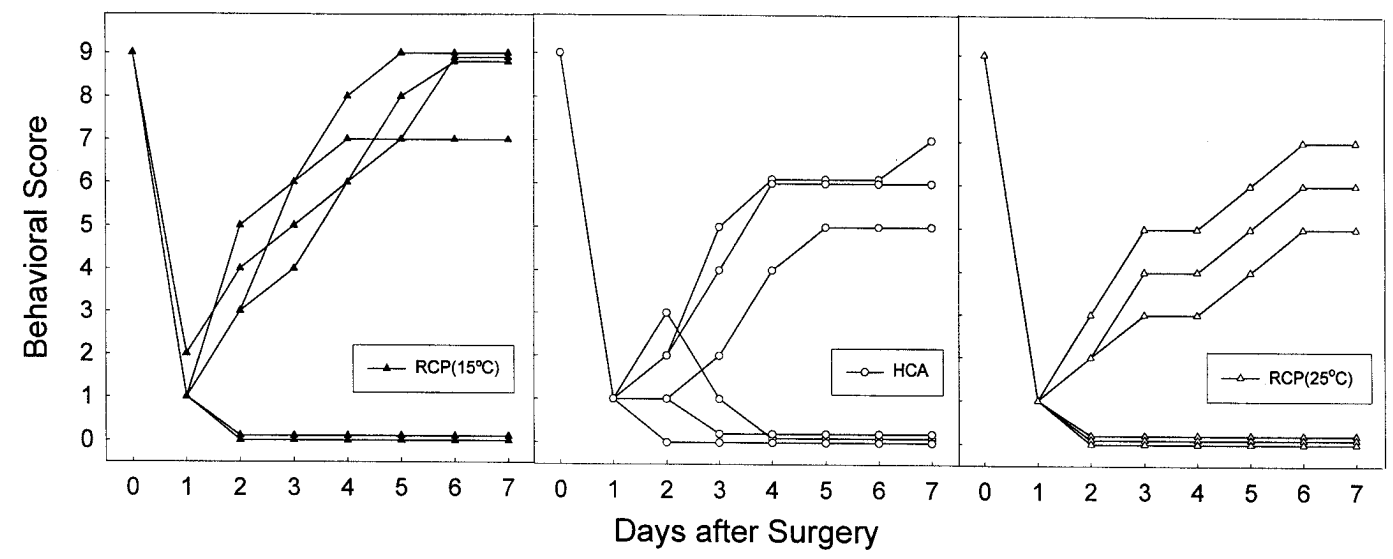

Fig 2. Daily scores indicating behavioral recovery after interventions. A score of 8 or 9 indicates essentially complete recovery, lower scores indicate substantial impairment, and 0 indicates coma or death. Behavioral scores starting on day 4 after operations on the surviving animals showed a significant difference between the groups. $\mathrm{RCP}\left(15^{\circ} \mathrm{C}\right)$ vs HCA, $P<.05 ; \mathrm{RCP}\left(15^{\circ} \mathrm{C}\right)$ vs $\mathrm{RCP}\left(25^{\circ} \mathrm{C}\right), P<.05$.

Table VI. Histopathologic scores in different regions of the brain and survival after 40-minute periods of HCA, $R C P\left(15^{\circ} \mathrm{C}\right)$, or $R C P\left(25^{\circ} \mathrm{C}\right)$ in 18 pigs

\begin{tabular}{|c|c|c|c|c|c|c|c|c|}
\hline Protocol & Pig No. & Survival (d) & Cortex & Thalamus & Hippocampus & $\begin{array}{c}\text { Posterior } \\
\text { brain stem }\end{array}$ & Cerebellum & Total score \\
\hline \multirow[t]{6}{*}{$\mathrm{HCA}$} & 1 & 7 & 0 & 2 & 1 & 2 & 0 & 5 \\
\hline & 2 & 7 & 2 & 3 & 1 & 2 & 2 & 10 \\
\hline & 3 & 3 & 2 & 2 & 0 & 2 & 0 & 6 \\
\hline & 4 & 2 & 1 & 2 & 0 & 2 & 2 & 7 \\
\hline & 5 & 7 & 2 & 2 & 2 & 2 & 2 & 10 \\
\hline & 6 & 1 & 2 & 0 & 0 & 0 & 1 & 3 \\
\hline \multirow[t]{6}{*}{$\mathrm{RCP}\left(25^{\circ} \mathrm{C}\right)$} & 1 & 7 & 3 & 0 & 0 & 2 & 1 & 6 \\
\hline & 2 & 1 & 2 & 2 & 0 & 0 & 1 & 5 \\
\hline & 3 & 7 & 3 & 0 & 2 & 2 & 2 & 9 \\
\hline & 4 & 1 & 2 & 0 & 2 & 2 & 2 & 8 \\
\hline & 5 & 1 & 1 & 2 & 2 & 2 & 1 & 8 \\
\hline & 6 & 7 & 3 & 0 & 0 & 2 & 1 & 6 \\
\hline \multirow[t]{6}{*}{$\mathrm{RCP}\left(15^{\circ} \mathrm{C}\right)$} & 1 & 7 & 1 & 2 & 1 & 2 & 1 & 7 \\
\hline & 2 & 1 & 2 & 2 & 0 & 2 & 1 & 7 \\
\hline & 3 & 7 & 2 & 2 & 0 & 0 & 0 & 4 \\
\hline & 4 & 7 & 1 & 0 & 0 & 2 & 1 & 4 \\
\hline & 5 & 7 & 2 & 2 & 0 & 2 & 0 & 6 \\
\hline & 6 & 1 & 0 & 0 & 1 & 0 & 0 & 1 \\
\hline
\end{tabular}

0 , No morphologic damage; 1 , edema, occasional dark neurons, or both; 2, numerous dark neurons and eosinophilic or dark-shrunk cerebellar Purkinje cells or hemorrhages; 3 , clearly infarctive foci.

the central nervous system. ${ }^{15}$ In pigs, competent jugular vein valves are rare, and therefore this model is frequently used in RCP studies. We did not look at jugular veins in postmortem examinations, but as seen in Table V, all animals undergoing RCP had a uniform flow pattern.

The implementation of RCP is shown to be a twoedged sword. In the laboratory with this chronic porcine model, effective RCP seems to require relatively high perfusion pressures obtainable only through pressurization of the entire venous system. ${ }^{8,9}$ By this means, effective retrograde flow can be generated, and significant removal of emboli can be achieved. ${ }^{8}$ However, clamping of the IVC increases the risk of perfusion-induced cerebral injury, which most likely is a consequence of the development of cerebral 


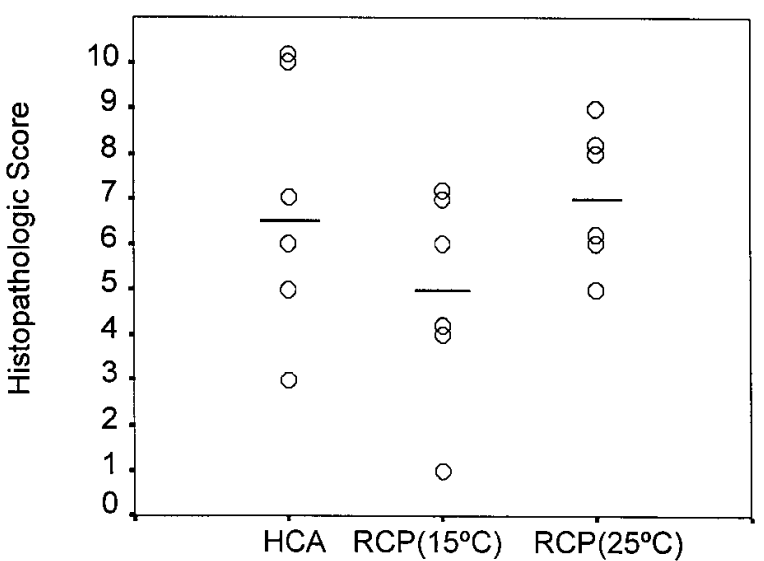

Fig 3. Total histopathologic scores of 18 pigs undergoing 40minute periods of $\mathrm{HCA}, \operatorname{RCP}\left(25^{\circ} \mathrm{C}\right)$, or $\operatorname{RCP}\left(15^{\circ} \mathrm{C}\right)$. The scores in the $\mathrm{RCP}\left(15^{\circ} \mathrm{C}\right)$ group were significantly lower than those found in the $\operatorname{RCP}\left(25^{\circ} \mathrm{C}\right)$ group $(P=.04)$.

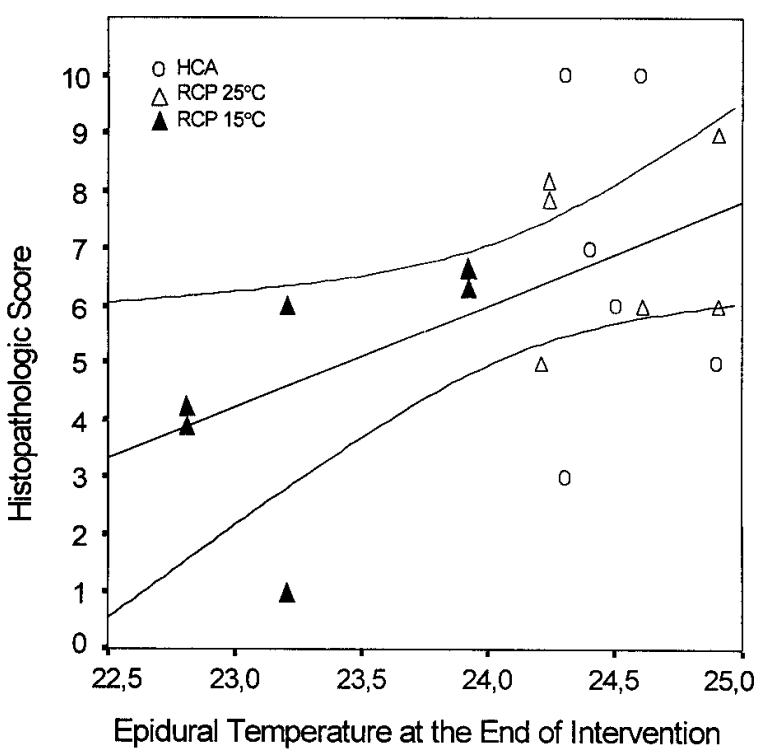

Fig 4. Epidural temperatures recorded at the end of 40minute periods of $\mathrm{HCA}, \operatorname{RCP}\left(25^{\circ} \mathrm{C}\right)$, or $\operatorname{RCP}\left(15^{\circ} \mathrm{C}\right)$ were found to be correlated with histopathologic scores $(\tau=0.27$, $P=.07)$. Individual scores are shown with linear regression and $95 \%$ confidence interval lines.

edema. ${ }^{8,9}$ Improved outcome after treating cerebral edema with aggressive pharmacologic intervention has been demonstrated. ${ }^{10,16,17}$ The retrograde flow, even in the presence of deep hypothermia, is far too small to meet the metabolic demand of the brain. ${ }^{13}$ It is possible, however, that the trickle flow supplied by RCP may allow removal of some metabolites and delay the development of severe acidosis of the ischemic brain.

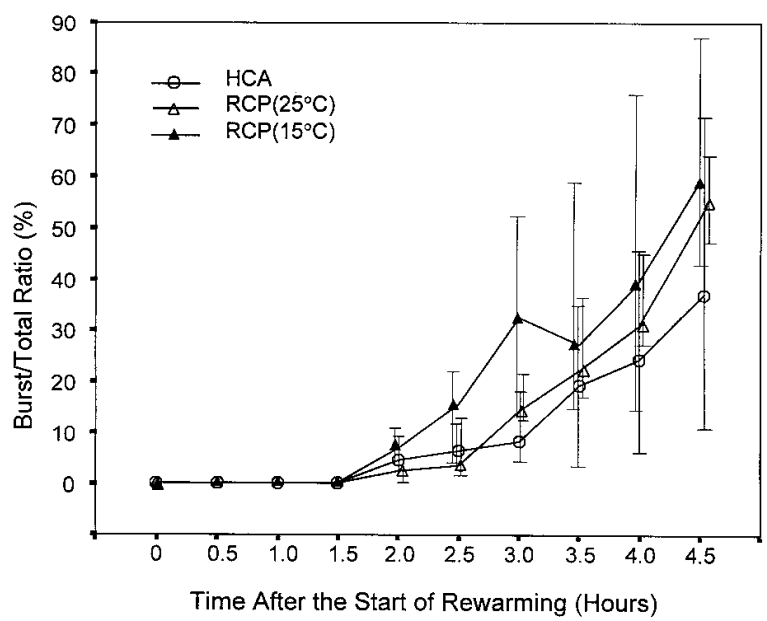

Fig 5. Medians with IQRs for total EEG burst ratios (relative to baseline) of 18 pigs undergoing 40-minute periods of $\mathrm{HCA}, \operatorname{RCP}\left(25^{\circ} \mathrm{C}\right)$, or $\mathrm{RCP}\left(15^{\circ} \mathrm{C}\right)$. EEG bursts were recovered significantly better in the $\operatorname{RCP}\left(15^{\circ} \mathrm{C}\right)$ group at the time point 3 hours after the start of rewarming compared with HCA group $(P=.05)$.

We selected systemic temperature of $25^{\circ} \mathrm{C}$ at which intervention was performed because one demand addressed for RCP in the clinical setting is to shorten CPB time and thereby to avoid subsequent problems, such as bleeding complications. At this temperature, the cerebral metabolism rate of oxygen is shown to remain both in pigs and human subjects at approximately $40 \%$ of baseline, and the predicted safe interval of circulatory arrest is 15 minutes. ${ }^{18,19}$ The poor outcome data in HCA animals seen in the present study indicated that the temperature and the length of intervention were appropriate.

The effect of cold and moderately cooled RCP was previously studied by using an acute dog model. ${ }^{20}$ The number of abnormal hippocampal neurons after 2 hours of ischemia was significantly lower in $10^{\circ} \mathrm{C} \mathrm{RCP}$ compared with moderately cooled RCP. As in the present study, no significant difference between HCA and cold RCP was seen. The present studies shed more light for these observations, and it seems especially important to remember that laboratory studies, which do not include some reliable measures of neurologic outcome, must be interpreted with caution.

The present EEG data are in line with the previous findings, suggesting that RCP-related cerebral injury occurs most likely during the reperfusion phase. ${ }^{8,9}$ Almost complete recovery of brain stem-evoked responses were seen immediately after the beginning of rewarming in animals that had undergone RCP, but this activity disappeared shortly afterward. ${ }^{8}$ We were able 
to repeat the EEG recovery pattern seen in our previous study. ${ }^{12}$ As shown in Fig 5, EEG activity after cold RCP recovered faster compared with that found in both of the two groups, with the difference being highest 3 hours after the start of rewarming. After that time point, however, a striking drawback was seen in animals who had undergone cold RCP, a finding emphasizing the previously set hypothesis that RCP exposes the brain for reperfusion injury. ${ }^{13}$ We believe that this phenomenon is most likely related to the development of brain edema after RCP, as documented also by other investigators. ${ }^{10,16,17}$

In conclusion, this study showed that the cold RCP at moderate systemic hypothermia seems to provide better neurologic outcome compared with moderate-temperature RCP, a finding suggesting that the enhanced cranial hypothermia is the major beneficial factor of RCP when careful attention is paid on its implementation.

We thank Randall B. Griepp, MD, who generously permitted us to use this animal model; Seija Seljänperä, RN, Veikko Lähteenmäki, Kauko Korpi, RN, and Jussi Rimpiläinen, MD, for technical assistance; and Pasi Ohtonen, medical biostatistician, for help in statistical analysis.

\section{REFERENCES}

1. Mills NL, Ochsner JL. Massive air embolism during cardiopulmonary bypass: causes, prevention, and management. J Thorac Cardiovasc Surg 1980;80:708-17.

2. Ueda Y, Miki S, Kusuhara K, et al. Surgical treatment of aneurysm or dissection involving the ascending aorta and aortic arch, utilizing circulatory arrest and retrograde cerebral perfusion. J Card Surg 1990;31:553-8.

3. Coselli JS. Retrograde cerebral perfusion is an effective means of neural support during deep hypothermic circulatory arrest. Ann Thorac Surg 1997;64:908-12.

4. Ueda Y, Miki S, Okita Y, et al. Protective effect of continuous retrograde cerebral perfusion on the brain during deep hypothermic systemic circulatory arrest. J Card Surg 1994;9:584-94.

5. Usui A, Abe T, Murase M, et al. Early experience of retrograde cerebral perfusion. Cardiovasc Surg 1997;5:510-5.

6. Safi HJ, Letsou GV, Iliopoulos DC, et al. Impact of retrograde cerebral perfusion on ascending aortic and arch aneurysm repair. Ann Thorac Surg 1997;63:1601-7.
7. Okita Y, Takamoto S, Ando M, et al. Mortality and cerebral outcome in patients who underwent aortic arch operations using deep hypothermic circulatory arrest with retrograde cerebral perfusion: no relation of early death, stroke, and delirium to the duration of circulatory arrest. J Thorac Cardiovasc Surg 1998;115: 129-38

8. Juvonen T, Weisz DJ, Wolfe D, et al. Can retrograde perfusion mitigate cerebral injury following particulate embolization? J Thorac Cardiovasc Surg 1998;115:1142-59.

9. Juvonen T, Zhang N, Wolfe D, et al. Retrograde cerebral perfusion enhances cerebral protection during prolonged hypothermic circulatory arrest: a study in a chronic porcine model. Ann Thorac Surg 1998;66:38-50.

10. Nojima T, Magara T, Nakajima Y, et al. Optimal perfusion pressure for experimental retrograde cerebral perfusion. J Card Surg 1994;9:548-59.

11. Boeckxstaens CJ, Flameng WJ. Retrograde cerebral perfusion does not perfuse the brain in nonhuman primates. Ann Thorac Surg 1995;60:319-27.

12. Anttila V, Kiviluoma K, Pokela M, et al. Cold retrograde cerebral perfusion improves cerebral protection during moderate hypothermic circulatory arrest: a study in a chronic porcine model. J Thorac Cardiovasc Surg 1999;118:938-45.

13. Griepp RB, Juvonen T, Griepp EB, et al. Is retrograde cerebral perfusion an effective means of neural support during deep hypothermic circulatory arrest? Ann Thorac Surg 1997;64:913-6.

14. Watanabe T, Iijima Y, Abe K, et al. Retrograde brain perfusion beyond the venous values: hemodynamics and intracellular $\mathrm{pH}$ mapping. J Thorac Cardiovasc Surgery 1996;111:36-44.

15. de Brux JL, Subayi JB, Pegis JD, Pillet J. Retrograde cerebral perfusion: anatomic study of the distribution of blood to the brain. Ann Thorac Surg 1995;60:1294-8.

16. Yoshimura N, Okada M, Ota T, Nohara H. Pharmacologic intervention for ischemic brain edema after retrograde cerebral perfusion. J Thorac Cardiovasc Surg 1995;109:1173-81.

17. Usui A, Oohara K, Liu TL, et al. Determination of optimum retrograde cerebral perfusion conditions. J Thorac Cardiovasc Surg 1994;107:300-8

18. McCullough JN, Zhang N, Reich D, et al. Cerebral metabolic suppression during hypothermic circulatory arrest in humans. Ann Thorac Surg 1999;67:1895-9.

19. Ehrlich MP, McCullough J, Juvonen T, et al. Effect of hypothermia on cerebral blood flow and metabolism in the pig. Surg Forum 1998;49:256-8.

20. Imamaki M, Koyanagi H, Hashimoto A, et al. Retrograde cerebral perfusion with hypothermic blood provides efficient protection of the brain: a neuropathological study. J Card Surg 1995;10:325-33.

\section{Targeted}

The Journal of Thoracic and Cardiovascular Surgery gives you two tables of contents.

The condensed table of contents tells you at a glance what topics and authors are presented each month. The expanded table of contents gives you a brief abstract of each article. You select only those articles of most interest to you for further reading. 